\title{
Sürdürülebilirlik, Tüketim ve Medya
}

\author{
FILIZZ AYDOĞAN BOSCHELE* \\ filiz30@yahoo.com \\ ORCID ID: 0000-0002-7628-6151
}

Öz: Modern XXI. yüzyılın başlarında dünyanın karşılaştığı en önemli kriz, ekolojik krizdir. Bu krizi önleyecek çarelerden biri ise sürdürülebilirliktir. 2000'lerde ortaya atılan, pek çok makalede özellikle işletme alanının makalelerinde göz kamaştırıcı bir başlık olarak yer alan sürdürülebilirlik kavramı, bu makalenin konusunu teşkil etmektedir. Her ne kadar içerdiği anlam "zararsız", hatta "yararlı" gibi görünse de, aslında sürdürülebilirliğin tüketim ve medya yoluyla verili toplumsal sistemin kendini yeniden üretecek toplumsal koşulları yarattı̆̆ı, çevreyi korumaya dönük gibi görünen anlamının ise kapitalizmin bu yönünü mistifiye ettiği ortaya çıkmaktadır. Bu görüşten hareketle bu yazı, sürdürebilirlik nosyonunun ortaya çıkmasına neden olan ve sürdürülebilirliği ortaya çıkaran tüketim ile tüketimde medyanın oynadığı rolü eleştirel bir perspektiften tartışmaktadır.

Anahtar kelimeler: Ekolojik kriz, Medya, Tüketim, Sürdürülebilirlik

\section{Giriş}

XXI. yüzyılın başlarında dünyanın karşılaştığı en önemli kriz, ekolojik krizdir ve ve bu krizi önleyecek çarelerden biri de sürdürülebilirliktir. Bu nedenle, sürdürülebilirlik olgusu 1990'lı yılların başından itibaren Batı literatüründe pek çok bağlamda tartışılmaktadır. İnsanın tarım devriminden, hatta öncesinden itibaren çevresini tüketen bir varlık olduğundan hareket eden ve bu durumun günümüz toplumlarında yaşattığı olumsuzlukları en aza indirgemeye çalışan sürdürülebilirlik kavramının ortaya çıkışı, 1970’lerdeki ekolojik kriz ve Yeşil Hareket'le bağlantılandırılır. Bu dönemdeki ekolojik krizin en önemli nedeni, devletlerin büyümesi ve kalkınmacı politikalardır. Başka deyişle, kapitalist üretimin ve tüketimin ihtiyaca dönüştürülmesi, ekolojik krizin kaynağının en önemli nedenidir.

İşte ekolojik krize bir çare olarak önerilen sürdürülebilirlik, sürdürülebilir bir gelecek vaat eder. 2000'lerde ortaya atılan, pek çok makalede özellikle işletme alanının makalelerinde göz kamaştırıcı bir başlık olarak yer alan sürdürülebilirlik kavramı, bu makalenin konusunu teşkil etmektedir. Günümüzde ise hemen her yerde rastladığ1-

\footnotetext{
* Prof. Dr., Marmara Üniversitesi, İletişim Fakültesi.
} 
mız sürdürülebilirlik kavramı ve içerdiği anlam "zararsız", hatta "yararlı" gibi görünse de dikkatle incelendiğinde sürdürülebilirliğin ve tüketim ve medya yoluyla verili toplumsal sistemin kendini yeniden üretecek toplumsal koşulları yarattığı ve böylelikle çevreye dönük gibi görünen anlamının mistifiye edildiği ortaya çıkmaktadır. Bu görüşten hareketle bu yazı, sürdürebilirlik nosyonunun ortaya çıkmasına neden olan ve sürdürülebilirliği ortaya çıkaran tüketim ile tüketimde medyanın oynadığ 1 rolü eleştirel bir perspektiften tartışmaktadır.

\section{Sürdürülebilirlik}

Doğal sistemlerin uyum içinde kalması için ekolojinin ihtiyaçlarını üretebilmesi fikrinden yola çıkan sürdürülebilirlik kavramı, modern yaşamı devam ettirebilmek için doğal kaynakları kullanan uygarlı̆̆ın, etrafındaki doğal dünyayla nasıl uyum içinde yaşayacağ 1 üzerine odaklanır. Günümüzde, modern tüketici ve kentsel toplum her gün pek çok doğal kaynağı sömürür. Bir önceki yıla göre, \%40 daha fazla kaynağı tüketen günümüz toplumları için sürdürülebilir gelişme, çok büyük önem taşımaktadır. Bu nedenle, sürdürülebilirlik ve sürdürülebilir gelişme, ekonomik ve teknolojik olarak ortaya atılan gereksinimler ile yaşadığımız çevrenin korunmasına dönük gereksinimler arasında bir denge kurmaya çalışır. Örneğin, kullandığımız tüketim ürünlerinin organik olduğunu görmek, bizi rahatlatan bir duygudur.

İlhan Tekeli, Sürdürülebilirlik Kavramı Üzerinde İrdelemeler ${ }^{1}$ başlıklı makalesinde, sürdürülebilirlik kavramının ilk olarak 1977'de Dennis Pirages'in Sürdürülebilir Toplum kitabında gündeme geldiğini, 1978 yllında yayınlanan Dennis Hayes'in Sürdürülebilir Topluma Doğru İlk Adımlar: Onarımlar, Yeniden Kullanım, Geri Kazanımlar kitabı ile kavramın güncel kullanıma girdiğini belirtmiştir. Çevre hareketinde merkezi bir konum kazanması kısaca Brundtland komisyonu diye bilinen, Dünya Çevre ve Kalkınma Komisyonu'nun 1987 yılında yayınlanan Ortak Geleceğimiz adlı raporu sonrasında olmuştur. Sürdürülebilirlik kavramının evrensel bir ilke olarak benimsenmesi ise 1992 yllında Rio'da toplanan Çevre ve Kalkınma Konferansı'yla başlamıştır. Sürdürülebilirlik, küresel bir ortaklık anlayışı içinde gerçekleştirilebileceğinden "Birleşmiş Milletler Sürdürülebilir Kalkınma Komisyonu" kurulmuştur. ${ }^{2}$

Böylelikle, kamuoyu küresel anlamda sürdürülebilirlik kavramıyla, Birleşmiş Milletler bünyesinde çalışan Dünya Çevre ve Kalkınma Komisyonu'nun 1987 yılında yayımlamış olduğu Ortak Geleceğimiz adlı rapor ile tanışmıştır. Rapor sürdürülebilirlik kavramını: "İnsanlık; doğanın gelecek kuşakların gereksinimlerine cevap verme yeteneğini tehlikeye atmadan, günlük ihtiyaçları temin ederek, kalkınmayı sürdürülebilir kılma yeteneğine sahiptir" şeklinde tanımlamıştır. ${ }^{3} 1987$ yılından itibaren de sürdürülebilirlik kavramı, çevre için kullanılışı hale getirilmiş bir kavram olarak ortaya çımıştır. Bu amaçla kurumlar tarafından doğaya zarar vermeden insanlığın gelişmesine katkı veren pek çok sürdürülebilirlik projeleri yapılmaktadır.

1 İlhan Tekeli, “Sürdürülebilirlik Kavramı Üzerinde İrdelemeler”, Cevat Geray’a Armağan, der., Muhterem Orhan, Ankara: Mülkiyeliler Birliği Yayınları, 2001.

2 Tekeli, “Sürdürülebilirlik Kavramı”, s.729.

3 “Tarih Boyu Sürdürülebilirlik Kavramı ve Açılamaları”, erişim 20 Haziran, 2020, http://ekolojist.net/tarihboyu-surdurulebilirlik-kavrami-aciklamalari/. 
Ayrıca, şirketler sürdürülebilirlik endeksi oluşturmakta, sürdürülebilir kalkınma, sürdürülebilir kalkınmada iş dünyası ve sanayi, sürdürülebilir kalkınmada bilgi ve iletişim, biyoçeşitliliğin korunması ve sürdürülebilir kalkınma, iklim değişikliği ve sürdürülebilir kalkınma, yönetişim ve sürdürülebilir kalkınma olarak birçok proje karşımıza çıkmaktadır. ${ }^{4}$ Doğa adına ortaya çıkarılmış sürdürülebilirlik kavramının amacı, "doğadaki yoksulluğu azaltmak", "doğal kaynaklardan yararlanırken dünyadaki eşitliği sağlamak", "çevre dostu teknolojilerin ortaya çıkarılmasına zemin hazırlamak", "nüfus kontrolünü” sağlamaktır. Sürdürülebilirlik sadece çevre konusuyla da sınırlı kalmamıştır. 2005 yılında Dünya Sosyal Gelişim Zirvesi’nde, sürdürülebilir gelişmenin üç önemli alanından söz edilmiştir: ekonomik gelişme, sosyal gelişme, çevresel koruma. Bu zirvedeki Brundtland Komisyonu, bu kavramı gelecek kuşakların ihtiyaçlarını karşılamalarını tehlikeye atmadan, günümüzün ihtiyaçlarını karşılayabilen bir gelişme olarak tanımlamıştır. Başka deyişle, sürdürülebilirlik, yarını bugünden düşünmektir.

Yukarıdaki bilgilerden de anlaşılacağı gibi, sürdürülebilirlik doğanın, çevrenin, doğal kaynakların bu duruma gelmesinde toplumsal sistemin kendisini dışarıda bırakan bir yaklaşımdır. İnsanlığın doğayla olan etkileşimini uygarlığın gelişimine dayandıran toplumsal ekoloji yaklaşımından yola çıkan Bookchin ise suçluyu sadece teknolojiye ve nüfus artışına indirgemenin kolaycı bir çözüm yolu olduğundan söz eder. İnsanlığın doğayla olan etkileşimini uygarlığın gelişimine dayandıran Bookchin'e göre, var olan ekolojik sorunların kaynağı kökleşmiş toplumsal sorunlardır. Yani yaşanan tüm ekolojik problemlerin temelinde, ekonomik, kültürel etnik ya da toplumsal cinsiyete dayalı çatışmalar bulunmaktadır. Petrol ya da nükleer sızıntıları, iklim değişikliklerini toplumsal sorunlardan ayırmak mümkün değildir. Bu nedenle, kapitalist toplumun yarattığ çözmek mümkün değildir. Ne yazık ki kâr amaçlı ticaret, sanayideki büyüme ve sürekli ilerleme düsturlarıyla işlerliğini sürdüren kapitalizm ise sorunların kaynağında sadece teknolojiyi ya da nüfus artışını bulmaktadır. ${ }^{5}$ Başka deyişle, teknolojinin insanın mı yoksa toplumsal sistemin mi yararına işlediği, verili sistemin, kapitalizmin hiç de umurunda değildir.

Bilindiği gibi, Aydınlanma sonrasının insan merkezli düşüncesi içinde gelişen modernite projesinin sağladığı kültürel birikim, sanayi devrimini gerçekleştirmiş, üretim ve tüketim hızını artırmıştır. Bu dönemin insan merkezli ahlakı, ekolojik sistemin insan dışındaki ögelerine salt araçsal olarak yaklaşılmasını ve doğayı sadece insanların hazzını artırmanın, refahını geliştirmenin araçları ya da nesneleri olarak değerlendirilmesini de beraberinde getirmiştir. Bu durum nüfus artışına, üretim ve tüketimin daha önceki dönemlerde görülmedik bir hızla büyümesine ve küresel ekolojik sistemin çok ciddi tehtidlerle karşı karşıya kalmasına neden olmuştur. Ekolojik sistemin bu tür ciddi tehlikelerle karşı karşıya kalması sonucunda, eko-sistem insana, onu yok edebileceğinin işaretlerini vermeye başlamıştır. 1970’li yıllardan sonra

4 “Tarih Boyu Sürdürülebilirlik Kavramı ve Açılamaları”.

5 Murray Bookchin, Toplumsal Ekolojinin Felsefesi, çev., Rahmi G. Öğdül, İstanbul: Sümer Yayıncılık, 2017, s.911. 
gelişen çevre hareketi ise bu durumun sonucunda ortaya çıkmıştır. ${ }^{6} 1968^{\prime}$ in sosyal dayanışma, eşitlik ve demokrasi değerlerine dayanan "ütopyacı militanlığı”, çevre hareketinin de kökenini temsil etmiş ve kendisinden sonraki pek çok politik hareketi önemli ölçüde etkilemiştir. ${ }^{7}$

Yukarıda da belirtildiği gibi, sürdürülebilirliğin toplumsal bir yaklaşımla ele alınması savını öne süren bu yazı, dünyanın kaynaklarının azalmasında, sürdürülebilirlik nosyonunun ortaya çıkmasında şüphesiz en önemli nedenin tüketim etkinliği ve tüketim olanaklarındaki artış olduğundan yola çıkacaktır. Bu nedenle, tüketimin toplumsal rolü ve dönüşümü incelenmeden, sürdürülebilirlik çözümlerine inanmanın da mümkün olmadığı görülecektir.

\section{"Kıyametin Sınırında" Tüketim ve Medya}

Sut Jhally, tüketimin dünyaya verdiği zararlar konusundaki "Kıyametin Sınırında Reklamcılık" başlıklı çarpıcı makalesinde, kapitalist sistemde kârın sermaye sahibine dönmesi ve değerin yeniden "para” biçiminde gerçekleştirilmesi için, metanın üretildiğinde dağıtım, değiştokuş ve tüketim dolaşımına girmek zorunda olduğunu belirtir. Bu dolaşım, bir yerde kesintiye uğrarsa kapitalist sistem durgunlaşabilir ve çökebilir. Jhally bu nedenle, kapitalizmin herşey uğruna metaların satılmasını sağlamak zorunda olduğunu belirtmektedir (Örneğin, koronavirüs salgınında ABD’de ekonomiyi öncelikli olarak düşünen Trump ile New York Belediye Başkanı arasındaki çekişme). Bu nedenle kapitalizmin sorunu, kitle üretimi ile ilgili değildir; çünkü bu, zaten sanayi kapitalizmi döneminde çözülmüştür. Jhally günümüzde kapitalizmin sorununun, tüketim sorunu olduğunu savunmaktadır. ${ }^{9}$

Hatırlanacağı gibi XIX. yüzyıl boyunca kapitalist toplum canlılı̆̆ını üretkenlikten, biriktirmeden, doyumları erteleme ideolojilerinden sağlıyordu. Yalnızca toplumun üst kesimindekilere has bir etkinlik olan tüketim, aynı yüzyılın ikinci yarısından itibaren "tüketimin demokratikleştirilmesi” anlaşıyla birlikte toplumun geniş kesimlerine de açılmıştır. Bilim ve teknolojide ortaya çıkan yeniliklerin üretimde etkinliği arttırmanın bir yolu olarak kullanması ve bu amaçla verimliliğin getireceği refahtan çalışan kitlelerin de yararlandırılması anlayışı sayesinde, yalnızca egemen konumdaki kesimlerce sahip olunan, alt kesimlere karşı bir ayrıcalık ve üstünlük göstergesi olarak kullanılan tüketimin bağımlı konumdaki kesimlerden esirgenmesi anlayışı yıkılmıştır. Başka deyişle, çok çalışarak az tüketmek, Püriten ahlak öğretisi, yerini çalışmadan tüketmeye ya da çalışarak bir üst konuma geçmek, yerini çeşitli entrikalarla yükseltmek gibi yeni bir anlayışa, hazcı etiğe bırakmıştır. ${ }^{10}$

Özellikle Henry Ford'un 1910 yllında üretimde en yüksek verimliliğin sağlanması için montaj hattı sistemini Michigan'daki High Land fabrikasında başlatmasıyla bir-

6 Tekeli, “Sürdürülebilirlik Kavramı Üzerinde İrdelemeler”, s.731.

7 Jeremy Gilbert, Antikapitalizm ve Kültür, çev., Tuba Sağlam, İstanbul: Ayrıntı Yayınları, 2017, s.40.

8 Sut Jhally, "Kıyametin Sınırında Reklamcılık”, çev., Filiz Aydoğan, Birikim, 159 (2002), s.78.

9 Jhally, "Kiyametin Sinırında”, s.78.

10 Ünsal Oskay, “Popüler Kültürün Toplumsal Ortamı ve İdeolojik İşlevleri Üzerine”, Kitle İletişiminde Temel Yaklaşımlar, der., Korkmaz Alemdar ve Raşit Kaya, Ankara: Savaş Yayınları, 1983, s.177-178. 
likte, kitlesel üretim çağına geçiş başlatmıştır. Araba üretiminde detayların en ince ayrıntısına kadar hesaplandığı, çabuk eğitilebilen tek amaçlı işçilerin çalıştırıldığı montaj hattı, ucuz araba üreterek önceki dönemlerdeki üretim düzeyini geçmekle kalmamış, daha az gelişmiş olan kitle üretimi sistemlerini de devre dişı bırakacak verimliliğe ulaşmıştır. 1920'li yıllarda kitle üretiminin sanayide kullanımı, otomobil sanayisini de aşmıştır. Tüketim mallarının imalatçıları, kitle üretiminin, yarışmacı bir piyasada sağ kalabilmenin tek koşulu olduğunu anlamışlardır. Kitle üretiminden önce sanayi, sınırlı ve büyük ölçüde orta ve üst sınıf pazarına yönelik üretim yapmaktaydı. Kapasitesinin yükselmesiyle giderek artan üretim, tüketici sayısını arttırmaya yönelmiştir. Çünkü kitle üretimi, pazarları daha dinamik bir hale getirmedikçe, ulus çapında büyümedikçe, daha önce tüketicileri arasında bulunmayan toplumsal sınıfları da işin içine katmadıkça ve ideolojik olarak yayılmadıkça işlerlik kazanamazdı. Böylelikle, toplumsal değer, yeni üretim sistemlerinin ihtiyaçlarına uygun olarak tutumluluk yerine harcama haline gelmiştir.

Nasıl Ford montaj hattı için tek amaçlı makinelerden yararlanarak, geleneksel yöntemleri cüceleştiren bir hızda otomobil ürettiyse, kültür sanayisi de ucuz ve geleneksel yöntemleri cüceleştirecek şekilde "tüketici” üretmeye girişmiştir. Ürünün yararl1lık değeri ya da mekanik niteliğiyle ilgili geleneksel görüş, malların kitle üretiminin gerektirdiği hızda satılmasını sağlayamadığından, reklamcılar tüketicilerin içgüdülerine ve düşlerine seslenerek satın alma itkisini kışkırtmaya başlamışlardır. Tüketimin kitlesel ve ulusal piyasaya yönelik olduğu bu dönem, temelinde sanayideki seri üretim dünyasının bant sisteminin yattığı, Gramsci'nin Fordizm olarak nitelediği kapitalizm içinde yeni bir uygarlık dönemini kapsıyordu. Fordizm'deki seri üretim, standartlaşmış malları almakta istekli olması gereken bir tüketici kitleyi, kısaca, kitlesel tüketimi önceden varsaymaktaydı. Bu durumda tüketim, kitle tüketim normunun oluşturulmasında canalıcı bir öneme sahipti. Fordist üretim çağında işçi sınıfı ailesi, gençler, ev kadınları gibi geleneksel piyasanın tüketim kalıpları değişmiştir. Pazarlamacılar ve reklamcılar herkesin televizyon, buzdolabı, çamaşır makinesine sahip olduğu bir toplumda farklı bir dili aramaktadır. Reklamcıların amacı; renkler, sesler ve çağrışım yoluyla bireyleri metalarla özdeşleşmeye iten ve bireyselliği kışkırtan şeyler yakalamaktır. Bu tür bir dünyada orta sınıf büyümekte ve popüler erdem diğer sınıfları da içine almaktaydı. Ulus ve ulusun harcama örüntüleri homojenleştirilmişti.

Bu durum tam da neoliberal ideolojinin isterlerine uygun olarak, 1980'lerden başlayarak değişmiş ve Juliet Schor'un "yeni tüketimcilik” olarak adlandırdığı yeni bir durum ortaya çıkmıştır. XIX. yüzyıl liberalizminin temel varsayımlarını yeniden gündeme getiren pek çok politik düşünce ve uygulamalardan oluşan neo-liberalizm, 1970’lerin başlarında ortaya çıkmış ve yükselmiştir. Neo-liberalizmin 1980 ve 1990’larda yaşadığı dönüşüm ise daha spesifik piyasaları ve üretim sistemlerini ortaya çıkartmıştır. Bu durum, kültürel farklılıkların genişlemesine ve farklı bireysel yaşam tarzlarının ortaya çıkmasına neden olmuştur. Aslında neoliberalizmin gerçek amacı, piyasa ilişkilerini olabildiğince çok insanın etkinlik alanına yaygınlaştırabilmektir. Örneğin, 1950 ve 1960'larda yetişen nesiller tüketim topulumunun özgür- 
lüklerinden azami ölçüde faydalanmanın peşindeydi. Bu dönemin insanları artık zor zamanlarında devlete, sendikalara ya da yerel kuruluşlara ihtiyaç duymayacak kadar zengin hissettiklerinden, toplumsal kazanımlarını koruyacak ne bir radikal politikaya ne de kendilerini özdeşleştirecekleri iş̧̧i hareketine ilgi duymamışlardır. Neoliberalizmin, dünyanın geri kalanına dayatıldığı 1980'lerin sonunda, Sovyetler Birliğininin dağılması ile geleneksel sosyalizme alternatif olacak pek çok radikal hareketle karşılaşılmıştır. Zaten 1990'lı yıllarda sadece çevre hareketi değil, neo-liberal kapitalist politikalara karşı çıkmak üzere pek çok toplumsal hareket de ortaya çıkmışt1. ${ }^{11}$ Fordist döneme muhalif olan hareketler; ev kadınlığı toplumsal rolüne hapsolmuş kadınlardan, kitle kültürünün konformizminden sıkılmış gençlerden, çalışma ortamlarında daha fazla bağımsızlık arayan işçilerden, politik katılım ve özerklik taleplerinin karşılanmadığ Afrikalı nüfustan gelmişti. ${ }^{12}$

Tüketim açısından bu dönem seri üretimin sınırllıklarının fark edilmesiyle, sanayinin kaptanlığının reklamcılar ve pazarlamacıların eline geçtiği yeni bir düzendir. $\mathrm{Bu}$ düzende, tasarımcılar yenilik üretip, yaşam tarzlarını biçimlendirirken, vitrinler de mal satmak yerine, tarz satmaya dönüşmüştür (sürdürülebilirlik de bu yaşam tarzlarından biri durumuna gelecektir). Başka deyişle, artık komşular gibi olmak yerine, onlardan farklı olmak için bir eğilim oluşmuştur. ${ }^{13}$ İşte Juliet Schor'un "Yeni Tüketimcilik" dönemi olarak adlandırdığı dönem, eski dönemin Jones'larla yarışma rejiminden, toplumsal olarak daha az tehlikesiz ama daha fazla bilinmezlerle doludur. $\mathrm{Bu}$, kısmen referans gruplarının dikey olarak uzaması nedeniyledir. İnsanlar artık kendilerini ekonomik hiyerarşide kendilerinden üstündekilerle karşılaştırmaya ya da onların yaşam biçimlerini arzulamaya yatkındırlar. Microsoft'un Bill Gates’i ya da şirketin ikinci başkanı daha yaygın öykünmeci hedefler haline gelmişlerdir. $\mathrm{Bu}$ değişimin en önemli nedeni, komşuluğun önemli bir referans grubu olarak önemini kaybetmesidir. Komşuluğun benzer gelirlere sahip bireyleri içermesi nedeniyle, bir standart olarak komşuları kullanmak, insanları en yakınındakilerle karşılaştırma yaptırır. Ama toplumsal etkileşimin odağı olarak komşuluk değer kaybettiğinden, güven verme rolünü de kaybeder. Bunun yerine işyeri, tüketim karşılaştırmaları için bereketli bir yer haline gelir. Bu süreç, özellikle beyaz yakall, mesleksel işlere sahip evli kadınlar tarafından hızlandırılmıştır. Kadınlar işyerinde, banliyödeki tipik ev kadınından daha farklı referans gruplarına rastlarlar ve bu nedenle, bir üsttekiyle tüketim karşılaştırmaları yapmaları daha olasıdır.

Sanayi kapitalizmi dönemini modern çağın katı/ağır/yoğun dönemi, ticari kapitalizmden itibaren yaşanan gelişmeleri ise akışkan/hafif dönem olarak ayıran Z. Bauman da günümüzü akışkan dönem olarak nitelendirir. Seri üretim döneminden farklı, kişisel tüketim yoluyla bireysel tercihlerin en üst noktaya vardırıldığı, kollektif dayanışma ve belli başlı kimliklerin zayıfladığı ve yeni kimliklerin ortaya çıktığı bu dönemde rutin ve kalıcılık, bütünlük yoktur. Bu duruma benzer bir biçimde, tüketim de varlığını normlar olmaksızın sürdürmek zorundadır. Tüketime yön veren şeyler

11 Gilbert, Antikapitalizm ve Kültür, s.67.

12 Gilbert, Antikapitalizm ve Kültür, s.239.

13 Robin Murray, “Fordizm ve Post-Fordizm”, Yeni Zamanlar: 1990’larda Politikanın Değişen Çehresi, der., Stuart Hall ve Martin Jacques, çev., Abdullah Yılmaz, İstanbul: Ayrıntı Yayınları, 1995, s.48-53. 
normatif kurallar değil, baştan çıkarma, sayısı ve şiddeti artan arzular, hedefi belirsiz isteklerdir. ${ }^{14}$ Bu türden bir tüketim ortamında çevreci bir yaşam tercihi, bu ürünlerin hem pahalı hem de zor ulaşılabilir olması nedeniyle, üst sınıfların tüketim tercihi haline gelmesini sağlamaktadır.

\section{Bolluk Ekonomisinde Sürdürülebilirlik}

İşte sonu gelmez tüketim merakı, doğanın kaynaklarının sorumsuzca tüketilmesine yol açarken, 2007 Hükümetlerarası İklim Değişikliği Paneli Raporu'nda ${ }^{15}$, kutupların beklendiğinden daha hızlı eridiği, dünya emisyonunun oldukça yükseldiği ve bu dönemde sürdürülebilirlik çözümlerinin de yetmediğinden söz edilmiştir. Aynı dönemde, 2008 yılında ABD’deki ekonominin çöküşü ile kapitalizmin yeniden sorgulanması sonucunda, küresel ekonominin açgözlülüğüne bazılarının "Paylaşım Ekonomisi 16 "bazılarınınsa "Bolluk Ekonomisi” olarak adlandırdığı çözüm yolları bulunmuştur. ${ }^{17} \mathrm{Bu}$ ekonominin ortak noktası, küresel kapitalizmin çevre, ekonomi, enerji ve besin tedariği gibi konularda yarattığı sorunlara yanıt vermektir.

Bolluk ${ }^{18}$ adlı kitabında tek hedefi, ekonomik büyüme olan ve piyasanın başarısızlıklarını ve yol açtığı ekolojik problemleri görmezden gelen küresel açgözlü ekonomi yerine, alternatif sürdürülebilir bir ekonomi tasarımı yapan Schor, sosyo-ekonomik bir dönüşüm önerir. Amacı, sürdürülebilir yaşam tarzlarını arzu edilebilir bir alternatif olarak gören bir bolluk fikrini oluşturmaktır. Burada tabii ki sürdürülebilirlik kişisel bir fedakârlık gerektirir. Aslında bolluk, bir sürdürülebilir ekonomi hareketi stratejisidir. ${ }^{19}$ Jackson $^{20}$, McKibben ${ }^{21}$ ve Speth ${ }^{22}$ gibi, bu düşüncenin öncü aktivistleri, küresel kapitalizmin ekolojik olarak yıkıcı etkilerini gösterip yurttaşları daha az tüketme, daha az çalışma, sosyal hayatın tadını çıkarma, yerel topluluğunu oluşturma, yaratıcı serbest zaman sağlama gibi konularda ya da "sürdürülebilir ekonomi hareketi”nde birleştirmek ister. Bu yaklaşım medyada da göze çarpar; örneğin grist.org gibi web sitelerinde, Orion, Utne Reader gibi dergilerde, Guardian gibi gazetelerde de bu yaklaşım yaygındır. ${ }^{23}$

Amerikalı ekonomi bilimci Juliet Schor tarafından küresel ekonominin yarattı̆̆ı zararları azaltacak çözüm önerilerini sunduğu "bolluk" nosyonu, daha iyi bir gelecek projesi içerir ve sürdürülebilirlik çalışmaları gibi en yeni yeşil teknolojilere uyumlu olmamızı ister. Tipkı paylaşım ekonomisi gibi bolluk ekonomisi de kollektif sorun-

14 Zygmunt Bauman, Akışkan Modernite, çev., Okan Sinan Çavuş, İstanbul: Can Yayınları, 2017, s.122.

15 "Climate Change 2007: Synthesis Report", Intergovernmental Panel on Climate Change (IPCC), erişim 20 Haziran, 2020, https://www.ipcc.ch/site/assets/uploads/2018/02/ar4_syr_full_report.pdf.

16 Yeni bir yer ya da mal almak yerine; alanları, mahalleri ya da herhangi bir eşyayı, malı paylaşmayı anlatır.

17 Juliet B. Schor, Plenitude: The New Economics of True Wealth, New York: Penguin Press, 2010, s.13.

18 Schor, Plenitude: The New.

19 Schor, Plenitude: The New, s.11.

20 Tim Jackson, Prosperity without Growth?: The Transition to a Sustainable Economy, London: Earthscan, 2009. 21 Bill McKibben, Deep Economy: The Wealth of Communities and the Durable Future, Oxford: One World Publications, 2007.

22 James G. Speth, The Bridge at the End of the World, New Haven: Yale University Press, 2008.

23 Douglas B. Holt, "Why the Sustainable Economy Movement Hasn't Scaled: Toward a Strategy That Empowers Main Street", Sustainable Lifestyles and the Quest for Plenitude: Case Studies of the New Economy, der., Juliet B. Schor ve Craig J. Thomson, New Heaven: Yale University Press, 2014, s.203. 
lara mikro-eylemlerle makro-dengeyi koruma amacındaki tüketimin azaltılarak, eşyaların ve hizmetlerin paylaşılmasını kapsamakta ve bu ekonomi günümüzün çevre sorunlarına bir çare olarak sunulmaktadır. Kişisel mahremiyetine, mülkiyetine, kazancına düşkün bireyler için bu perspektif, bir ekonomik devrim olarak tanımlanmaktadır. ${ }^{24}$

Yeni bir yer ya da mal almak yerine; alanları, mahalleri ya da herhangi bir eşyayı, malı paylaşmayı anlatan paylaşım ekonomisi, Schor'un terimiyle "Bolluk Ekonomisi”, özellikle internetin yükselişiyle paralel gitmiştir. Dubois, Schor ve Carfagna buradaki tüketici deneyimini "bağlantılı tüketim" olarak tanımlarlar. Bağlantılılık, bu pratiklerin hem dijital hem de toplumsal yönünü gösterir. Paylaşım ekonomisi ya da bu bağlantılı tüketimin katılımcıları, bu ekonomiye ucuz olması, ekolojik olması ve sosyal bağlantılar yaratması gibi üç ana nedenle başvururlar. Bu insanlar dijital olarak birbirlerine bağlı, yabancılara, farklı deneyimlere ve yaşam tarzlarına bağlı, genellikle yüksek eğitimli, yüksek gelire sahip insanlardır. ${ }^{25}$

Douglas B. Holt, Why the Sustainable Economy Movement Hasn't Sacled: Toward A Strategy That Empowers Main Street ${ }^{26}$ başlıklı makalesinde, bu sürdürülebilir ekonomi hareketinin pek de yürümediğinden söz eder. Çünkü sürdürülebilir ekonomi uygulayıcıları "modern bohem bir altkültür" üyeleri olarak kalmaktadırlar. Üstelik Holt, bu sürdürülebilir bohem ideolojisinin, Amerikan üst-orta sınıfından pek çok kişiyi etkilediğini ve burjuva bohem ideolojisini kışkırtan yeni bir piyasayı ortaya çıkardığını belirtmektedir. ${ }^{27}$

Başka deyişle, sürdürülebilirlik politikalarının amacı da piyasaya kazandırmaktır. Başka deyişle tüketicilik, kesin bir biçimde, onu eleştirilmeyen bir şey olarak gören liberal ideolojiye köledir. Üreticilerin, reklamcıların ve pazarlamacıların ayartıcı, hatta karşı konulamaz yaratma çabalarıyla harcama örüntüleri, eskisinden çok daha fazla yaygınlaşmış ve sofistike hale gelmiştir. İşte sürdürülebilirlik ne yazık ki bu sofistikasyonun bir parçası olarak, ticarileşmenin de gölgesinde ve etkisindedir. Çünkü şirketler, çevre tahribini ve ekolojik yıkımı önemsediklerine dayalı halkla ilişkiler ve reklam kampanyalarıyla kamuoyunun dikkatini çekerek, yeni tüketiciler yaratmaktadir.

Felix Guattari, $\ddot{U} c ̧$ Ekoloji ${ }^{28}$ kitabında çevre sorunlarının sosyal, ekonomik, siyasi ve estetik sorunlarla birlikte düşünülmesi gerektiğini belirtmiştir. Çünkü sadece çevre değil; toplumdaki aile, komşuluk, yardımseverlik gibi mikro-ilişkilerden; devletlerarası siyaset, milliyetler arası etnik çarpışmalar gibi makro-ilişkilere kadar her şey kirlenmektedir. Tüm bunların sebebi ise, kâr amacı güden kapitalizm, kapitalist pa-

24 Emilie A. Dubois, Juliet B. Schor ve Linsey B. Carfagna, "New Cultures of Connection in a Boston”, Sustainable Lifestyles and the Quest for Plenitude: Case Studies of the New Economy, der., Juliet B. Schor ve Craig J. Thomson, New Heaven: Yale University Press, 2014, s.95.

25 Dubois, Schor ve Carfagna, "New Cultures of Connection in a Boston", s.96.

26 Holt, "Why the Sustainable Economy Movement Hasn't Scaled: Toward a Strategy That Empowers Main Street", s.203.

27 Holt, "Why the Sustainable", s.232.

28 Felix Guattari, Üç Ekoloji, çev., Ali Akay, İstanbul: Bağlam Yayıncılık, 2000. 
zar ve sermaye ilişkileri üzerine kurulu şirketlerin yanı sıra, yardımseverlik ve dayanışma üzerine kurulu şirketlerdir. Bu nedenle, Guattari’ye göre, dünyamızda pazar ekonomisinin diktatörlüğü sorgulanmalıdır.

Biyosferdeki dengesizlikler ve ozon tabakasının delinmesi, dünyamız için bir tehlike oluşturmaktadır; fakat Batı toplumlarının kendi içlerindeki fakirlerle evsiz barksızların sosyal durumları da sözkonusu olarak, ekolojik tartışma içine konulmalıdır. Geleceğe dair felaketlerle kafamız şişiriliyor, fakat aslında asıl felaket kapımızın önünde yatıyor. [...] Üretim için üretim yapmak, 'kar' hadlerini zorlamak ve üretilen malların 'insaniliğini biryana bırakmak' moda haline gelmektedir. Nietzsche'in 'insanın ölümü' teması, insanlığın yok olması demek değildir, tersine insanın bir makina-oluşa girmesi demektir. ${ }^{29}$

Bu durumdan kurtulmak için Guattari'nin önerisi tekno-bilime bağlı olan medya ve sanayiler ve bunun getirdiği çevre ekolojisi yerine, yani sadece doğa kirlenmesine karşı değil, her türlü vicdani, bilinç kirlenmesi anlayışını da içeren "zihinsel bir ekoloji” anlayışına geçilmektir. ${ }^{30}$

\section{Sonuç}

Uygarlığın ilk başarıları alet kullanmak, ateşi kontrol etmek ve kendilerini koruyacak barınaklar yapabilmektir. Alet kullanmaya başlamasıyla birlikte insan, kendi organlarını kusursuzlaştırmış ya da bu organların işlevlerini genişletmiştir. Aletler geliştirerek bedensel gücündeki eksiklikleri tamamlayan insan, ateşi bularak çevreye tutsaklıktan kurtulmaya başlamış, böylelikle doğaya egemen olabileceğini ve doğayı dilediği gibi biçimlendirebileceğini kanıtlamıştır. Özellikle sanayi devriminden itibaren yaşanan teknolojik, ekonomik gelişmeler de bu durumu devam ettirmiştir.

Başka deyişle, uygarlığın ortaya çıkmasında belirleyici olan şey, doğa üzerinde toplumsal denetimin sağlanması, doğadan ekonomik olarak yararlanılması, kısaca doğanın fethedilmesidir. Ancak, bilim ve teknolojideki gelişmeler sayesinde günümüzde doğanın fethi, doğaya ve insana zarar verecek boyuta ulaşmıştır. Sürdürülebilirlik yaklaşımına toplumsal açıdan bakıldığında sürdürülebilirlik, modern yaşamın getirdiği sanayileşme, kentleşme ve tüketim toplumunun doğa üzerinde yarattığ1 olumsuz sonuçların meyvesidir.

Sürdürülebilirliği tüketimin medya ile yaygınlaştırılması bağlamında ele alan bu yazı yüzyıllardır kapitalizm ve sermayenin hedefinin doğanın kapasitesini korumaktan çok doğayı kâra dönüştürmek olduğunu öne sürmektedir. Gerçekten de sanayi devriminden başlayarak bilim ve teknolojide yaşanan devasa gelişmeler, toplumsal ilişkilerin temelindeki eşitsizlik ilişkisini değiştirebilecek kültürel ve siyasal değişime sahip olmadığından, kitlelerin verili sistemin karşısında bir kültür oluşturamamasına neden olmaktadır. Bu durum ise, sürdürülebilirlik gibi, gene sistemin içinde kalarak ve yine sistemin kendisi tarafından üretilen çözümleri karşımıza çıkarmaktadır. Örneğin, elektrik enerjisini az tüketen eşyalar; ürünler, hep toplumsal sistemin ken- 
disi tarafından üretilmekte ve medya yoluyla kitlelere yeni bir tüketim ürünü, meta olarak sunulmaktadır. Üstelik, ekolojik bir yaşamı niteleyen gerek yiyecekler (glutensiz, laktozsuz, organik yiyecekler) gerekse kullandığımız eşyalar (elektrikli aletler, çevreye duyarlı poşetler, arabalar vs)A+(plus) olarak isimlendirilmekte, reklamlarda bu ürünlerin girdiği evler üst sınıfı resmedilmektedir. Fiyatları ise sıradan ürünlere göre çok daha yüksek olmakta, daha çok belirli bir sınıfı hedeflemekte ve bir yaşam tarzı olarak sunulup pazarlanmaktadır. Böylelikle, bu ürünlerden daha çok üst sınıflar yararlanabilmektedir.

Hatırlanacağı gibi daha önce de sanayideki çalışma düzeninin, çalışan kitleler üzerindeki baskısını ve insanlıktan çıkarıcı doğasını anlayan sosyalizm, sendikacılık, anarşizm, feminizm gibi akımlar, sanayi toplumuna yetkeyle sahip çıkan ve bundan kâr sağlayan egemen kesimi suçlayarak, toplumsal ilişkilerde değişiklik istediklerinde, kapitalizm, bu eleştirel ve kapitalizm karşıtı perspektifleri keşfetti ve kendisini olumlayacak yapıları da bu akımların eleştirilerinden çıkardı. Örneğin, kapitalizmin yükselişiyle geleneksel aile yapısı bozulunca kapitalizm, feminizmin ataerkil toplumun baskıcı olduğu görüşüne katılmıştır. Kadınların tarihsel olarak ezilmişliğini ataerkil aile yapısına bağlayan feminizm gibi, tekelci kapitalizm de baba yetkesine karşı çıkmıştır. Ama tabii bu karşı çıkış, varolan eşitsizliği değiştirmek için değil, bu eşitsizlikten yararlanarak, kadınlarda serbestçe tüketebilme ve tüketerek, tükettiğini göstererek eşitmiş gibi görünebilme yanılsamasını yaratabilmek nedeniyle yapılmıştır. Liberal dönemin ve püritenliğin teşvik ettiği çileciliğin tersine, günümüzde medya ve popüler kültür kapitalizmi eleştirmekte serbesttir. Bunun örneklerinde pek çok medya ürününde sıkça rastlarız.

Bugün geçerli olan ilke, sistemde var olan direnme olanaklarının kitlelerden gizlenebilmesi için, kitleleri kaçamayacak biçimde kıstırmaktır. Bunun sonucu olarak, kitle iletişim araçlarını da içine alan medya bir yandan tüketicilerin tüm gereksinmelerini karşılarken, öte yandan kitlelere, kendilerine sunulanla yetinmelerini önermektedir. Sürdürebilirlik, paylaşım ekonomisi, bolluk ekonomisi gibi XXI. yüzyılın moda terimleri, politikaları da kapitalizmin bireyleri sistem içinde tutma politikalarının bir başka versiyonudur.

Sanayi toplumlarıyla doğa, içinde oturulan ve "yaşanan" bir yer olmaktan çok; üretilen, çalışılan bir nesne durumuna girmiştir. Teknik ve uygarlık bu doğayı işlevleştirip, bozmaktadır. Çevresini tüketen bir varlık olarak insanın eylemlerini düzenlemeye çalışan sürdürülebilirlik kavramına medyanın katkısı açısından baktığımızda, çok da masum görünmemektedir. Çünkü sürdürülebilirlik, doğaya ve insana zarar veren verili sistemi tümden değiștirmek yerine, bu zararları en aza indirgeyerek, tamir etme ve böylelikle de verili sisteme karşı politikaların üretilebilmesini engellemekte hatta yeniden üretimi amacını taşımaktadır.

Sonuç olarak sürdürülebilirlik, kapitalizmin ve kurumlarının kendi sürdürülebilirliği için bir stratejidir. Bu nedenle, dünyanın sürdürülebilirliğini verili toplumsal düzene toz kondurmadan birkaç şirket ya da insan eylemine bağlamak ve çözüm aramak, belkemiğini rekabetin, değişim değerinin oluşturduğu bu düzende, her gün 
tüketimi özendiren öyküleriyle medyada bunun mümkün olduğunu söylemek, safdillik olur. Bu nedenle sürdürülebilirlik, tüketim ve tüketimin son bulmaması için pek çok stratejiyle kitleleri elinde tutan ve medyayı da içine alan pek çok bağlamda tartışılması gereken toplumsal bir olgudur.

\section{Kaynakça}

Bauman, Zygmunt. Akışkan Modernite. Çev., Okan Sinan Çavuş. İstanbul: Can Yayınları, 2017.

Bookchin, Murray. Toplumsal Ekolojinin Felsefesi. Çev., Rahmi G. Öğdül. İstanbul: Sümer Yayıncilık, 2017.

Çevre, Dünya ve Kalkınma Komisyonu. Ortak Geleceğimiz Raporu. Ankara: Türkiye Çevre Sorunları Vakfı Yayını, 1991.

Dubois, Emilie A., Juliet B. Schor ve Linsey B. Carfagna. "New Cultures of Connection in a Boston". Sustainable Lifestyles and the Quest for Plenitude: Case Studies of the New Economy. Haz., Juliet B. Schor ve Craig J. Thomson. New Heaven: Yale University Press, 2014.

Ekolojist. “Tarih Boyu Sürdürülebilirlik Kavramı ve Açıklamaları”. Erişim 20 Haziran, 2020. http://ekolojist.net/tarih-boyu-surdurulebilirlik-kavrami-aciklamalari/.

Gilbert, Jeremy. Antikapitalizm ve Kültür. Çev., Tuba Sağlam. İstanbul: Ayrıntı Yayınları, 2017.

Guattari, Felix. Üç Ekoloji. Çev., Ali Akay. İstanbul: Bağlam Yayıncılık, 2000.

Holt, Douglas B. "Why the Sustainable Economy Movement Hasn't Scaled: Toward a Strategy That Empowers Main Street". Sustainable Lifestyles and the Quest for Plenitude: Case Studies of the New Economy. Der., Juliet B. Schor ve Craig J. Thomson. New Heaven: Yale University Press, 2014.

Intergovernmental Panel on Climate Change (IPCC). "Climate Change 2007: Synthesis Report”. Erişim 20 Haziran, 2020. https://www.ipcc.ch/site/assets/ uploads/2018/02/ar4_syr_full_report.pdf.

Jackson, Tim. Prosperity without Growth?: The Transition to a Sustainable Economy. London: Earthscan, 2009.

Jhally, Sut. "Kıyametin Sınırında Reklamcılık". Çev., Filiz Aydoğan. Birikim. 159 (2002): 77-86.

McKibben, Bill. Deep Economy: The Wealth of Communities and the Durable Future. Oxford: One World Publications, 2007.

Murray, Robin. “Fordizm ve Post-Fordizm”. Yeni Zamanlar: 1990’larda Politikanin Değişen Çehresi. Der., Stuart Hall ve Martin Jacques. Çev., Abdullah Yılmaz. İstanbul: Ayrıntı Yayınları, 1995.

Oskay, Ünsal. "Popüler Kültürün Toplumsal Ortamı ve İdeolojik İşlevleri Üzerine”. Kitle İletişiminde Temel Yaklaşımlar. Der., Korkmaz Alemdar ve Raşit Kaya. Ankara: Savaş Yayınları, 1983.

Schor, Juliet B. Plenitude: The New Economics of True Wealth. New York: Penguin Press, 2010. 
Speth, James G. The Bridge at the End of the World. New Haven: Yale University Press, 2008.

Tekeli, İlhan. "Sürdürülebilirlik Kavramı Üzerinde İrdelemeler". Cevat Geray’a Armağan. Der., Muhterem Orhan. Ankara: Mülkiyeliler Birliği Yayınları, 2001. 
İNSAN\&İNSAN, Y1l/Year 7, Say1/Issue 26, Güz/Fall 2020, 11-23

DOI: https://doi.org/10.29224/insanveinsan.757873

\section{Sustainability, Consumption and Media}

FiLIZZ AYDOĞAN BOSCHELE

Abstract: Since The most important crisis that the orld is facing at the beginning of the 21st century is an ecological crisis and its prevention is sustainability. The subject of this article is the concept of sustainability, at the beginning of the 2000s, in Business Administration articles "stunning" titles. Although, the meaning of sustainability seems "harmless" or "useful", this concept mystifies capitalist reproduction through the media and consumption. From this point of view, this paper will critically discuss the consumption which is the cause of the rise of the notion of sustainability and the media's role for consumption.

Keywords: Ecological crisis, Media, Consumption, Sustainability 